\title{
PDE5 inhibitors as potential tools in the treatment of cystic fibrosis
}

\section{Sabrina Noel ${ }^{\dagger}$, Barbara Dhooghe ${ }^{\dagger}$ and Teresinha Leal *}

Louvain Centre for Toxicology and Applied Pharmacology, Institut de Recherche Expérimentale et Clinique, Secteur des Sciences de la Santé, Université Catholique de Louvain, Brussels, Belgium

Edited by:

Marc Chanson, University of Geneva, Switzerland

\section{Reviewed by:}

Marc Chanson, University of Geneva Switzerland

Jacky Jacquot, Université Reims

Champagne Ardenne, France

\section{*Correspondence:}

Teresinha Leal, Louvain Centre for Toxicology and Applied Pharmacology, 10 Avenue Hippocrate 10, B1200

Brussels, Belgium.

e-mail: teresinha.leal@uclouvain.be

${ }^{+}$Sabrina Noel and Barbara Dhooghe have contributed equally to this work.
Despite great advances in the understanding of the genetics and pathophysiology of cystic fibrosis (CF), there is still no cure for the disease. Using phosphodiesterase type 5 (PDE5) inhibitors, we and others have provided evidence of rescued F508del-CFTR trafficking and corrected deficient chloride transport activity. Studies using PDE5 inhibitors in mice homozygous for the clinically relevant F508del mutation have been conducted with the aim of restoring F508del-CFTR protein function. We demonstrated, by measuring transepithelial nasal potential difference in F508del mice following intraperitoneal injection of sildenafil, vardenafil, or taladafil at clinical doses are able to restore the decreased CFTR-dependent chloride transport across the nasal mucosa. Moreover, vardenafil, but not sildenafil, stimulates chloride transport through the normal CFTR protein. We developed a specific nebulizer setup for mice, with which we demonstrated, through a single inhalation of PDE5 inhibitors, local activation of CFTR protein in CF. Significant potential advantages of inhalation drug therapy over oral or intravenous routes include rapid onset of pharmacological action, reduced systemic secondary effects, and reduced effective drug doses compared to the drug delivered orally; this underlines the relevance and impact of our work for translational science. More recently, we analyzed the bronchoalveolar lavage of $\mathrm{CF}$ and wild-type mice for cell infiltrates and expression of pro-inflammatory cytokines and chemokines; we found that the CFTR activating effect of vardenafil, selected as a representative long-lasting PDE5 inhibitor, breaks the vicious circle of lung inflammation which plays a major role in morbi-mortality in CF. Our data highlight the potential use of PDE5 inhibitors in CF. Therapeutic approaches using clinically approved PDE5 inhibitors to address F508del-CFTR defects could speed up the development of new therapies for CF.

Keywords: CFTR, cystic fibrosis, PDE5 inhibitors, sildenafil, vardenafil, taladafil

\section{INTRODUCTION}

Approximately 80,000 people in the world are diagnosed with Cystic Fibrosis (CF), the most common, life-threatening, recessively inherited disease in Caucasian populations. Affecting about one newborn in every 2,500 live births, CF is due to mutations in the CF transmembrane conductance regulator (CFTR) gene (Kerem et al., 1989; Riordan et al., 1989) which encodes the main chloride channel expressed in epithelia. CF disease causes abnormal mucociliary clearance mainly in the lungs, leading to a vicious cycle of obstruction/infection/inflammation that progressively and irreversibly damages lung tissue and architecture. Many organs are affected in CF but pulmonary disease is the major cause of morbidity and mortality (Rowe et al., 2005; Davis, 2006). Although life expectancy and quality of life have progressively improved over time, there is still no cure for CF.

The most common disease allele, F508del, corresponding to a deletion of a single phenylalanine residue at position 508 of a single polypeptide chain of 1480 amino acids, prevents the efficient folding of the CFTR protein. The F508del-CFTR protein is correctly translated but it is retained in the endoplasmic reticulum and directed toward proteosomal degradation (Lukacs et al., 1994). As a consequence, expression of the misfolded, immature, partly glycosylated F508del-CFTR protein at apical membranes is reduced, leading to a loss-of-function of transepithelial chloride transport.

Recent research in CF basic science has focused on the discovery of pharmacological therapies directed to treat mutation-specific changes (for review, Lubamba et al., 2012a). In the case of the F508del-CFTR mutation, efforts have been made to correct localization of the mutant protein by favoring its expression at the apical membrane of cells. However, it has been recognized that rescuing F508del-CFTR to the plasma membrane does not completely correct chloride transport abnormalities as it also displays reduced channel activity (Amaral, 2004). Therefore, finding a compound that also promotes CFTR channel activity would be of a great benefit. Searching for such compounds, we and others have demonstrated the potential of inhibitors of phosphodiesterase type 5 (PDE5), such as sildenafil, vardenafil, and taladafil, for the treatment of CF. Indeed, recent findings have evidenced that the drugs, already in clinical use for the treatment of erectile dysfunction and of pulmonary arterial hypertension, are able to rescue F508del-CFTR trafficking (Dormer et al., 2005; Robert et al., 2008) and to improve its channel activity (Lubamba et al., 2008, 2011). 


\section{CYCLIC NUCLEOTIDE PHOSPHODIESTERASES}

PDE activity is found in all cells, but with a distinct cellular and subcellular distribution of the 11 mammalian isoforms (Beavo et al., 1970). By catalyzing the hydrolysis of $3^{\prime}$ cyclic phosphate bonds of adenosine and/or guanosine $3^{\prime} 5^{\prime}$ cyclic monophosphate (cAMP and/or cGMP) the enzyme regulates the intracellular levels of the second messengers. The multiple isoforms of PDEs and their 50 or so subtypes, displaying different kinetics and regulatory properties (Cheung, 1970; Conti, 2000; Soderling and Beavo, 2000; Francis et al., 2001; Mehats et al., 2002), are characterized by their specificity and sensitivity to calcium-calmodulin and their affinity for cAMP or cGMP (Figure 1).

Eleven families of PDE have been identified in mammalian tissues (Cheung, 1970; Conti, 2000; Soderling and Beavo, 2000; Francis et al., 2001; Mehats et al., 2002) and are classified on the basis of their amino acid sequences, substrate specificities, pharmacological properties, and tissue distributions (Table 1).

\section{PDE INHIBITORS: MAIN CHARACTERISTICS AND CLINICAL APPLICATIONS}

Inhibition of PDEs leads to increasing intracellular concentrations of endogenous cAMP/cGMP (Bender and Beavo, 2006). Therefore, inhibition of PDE can mediate a variety of physiological mechanisms at different cell and organ levels. Strategies directed to promote inhibition of PDE activity have been applied as therapeutic tools in a variety of lung and inflammatory disorders, such as asthma and chronic obstructive pulmonary disease (COPD) but also in neuronal, cardiovascular, and other conditions (Table 1).

Many selective and non-selective PDE inhibitors have been explored as therapeutic agents. PDE1s are calcium- and calmodulin-dependent activators or regulators (Ahn et al., 1991; Yan et al., 1995; Loughney et al., 1996; Yu et al., 1997). Several isoforms have been recognized exhibiting different affinities for cAMP and cGMP. PDE1 inhibition has been investigated in treating neuronal plasticity (Medina et al., 2006; Menniti et al., 2006), detrusor instablities and urgency incontinence (Truss et al., 2001), memory loss (Zhang et al., 2004), reversal of the effects of early alcohol exposure in learning performance in the water maze (Jeon

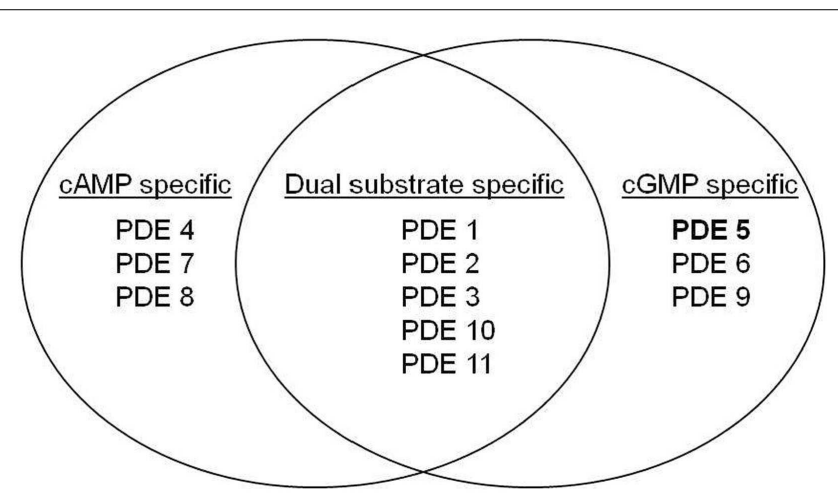

FIGURE 1 | Substrate specificity of the different families of PDE. Although a high degree of homology has been observed within the catalytic domain of PDEs, slight structural differences in these domains determine the specificity of substrate of PDEs (Xu et al., 2004). et al., 2010) and Parkinson and Alzheimer diseases (Reed et al., 2002). It was recently demonstrated that vinpocetine has a strong anti-inflammatory effect (Filgueiras et al., 2010; Medina, 2010).

PDE2, which metabolizes both cGMP and cAMP (Rosman et al., 1997), is highly expressed in heart (Rivet-Bastide et al., 1997) and brain but lower expression levels are found in a variety of organs (Sadhu et al., 1999). PDE2 inhibitors identified so far lack therapeutic actions (Repaske et al., 1992; Podzuweit et al., 1995; Suvarna and O'Donnell, 2002; Boess et al., 2004; Rutten et al., 2009).

It is well known that methylxanthines, non-selective PDEs found in tea, coffee, and cocoa, stimulate the central nervous system, relax the bronchial smooth muscle, and stimulate cardiac muscle. Methylxanthines have long been used as therapeutic agents in respiratory diseases (Sullivan et al., 1994; Barnes, 2003a,b,c; Bhatt-Mehta and Schumacher, 2003; Barnes and Stockley, 2005; Muller and Jacobson, 2011). Indeed theophylline (1,3dimethylxanthine) and other methylxanthines have been used in medical practice long before they were identified as PDE inhibitors. Caffeine has long been used as a bronchodilating agent. It has been perceived that theophylline has additional antiinflammatory properties for use in asthma or COPD, diseases characterized by inflammatory and immune responses. Paraxanthine (1,7-dimethylxanthine), the primary metabolite of caffeine (1,3,7-trimethylxanthine), acts through the ryanodine receptor to elevate intracellular calcium concentration and increases viability of neuronal cells in culture (Guerreiro et al., 2008). The synthesized 3-isobutyl-1-methylxanthine (IBMX) has a much higher affinity for PDEs and, at low concentrations, it preferentially inhibits cGMP-dependent over cAMP-dependent PDEs (Wells et al., 1975). Moreover, methyxanthines are potent antagonists of adenosine receptors (Muller and Jacobson, 2011).

PDE3 are non-selective enzymes with high affinity for both cAMP and cGMP (Palmer and Maurice, 2000). A large number of selective PDE3 inhibitors including milrinone, cilostamide, and cilostazol have been identified as potential therapeutic tools for cardiovascular diseases and asthma (Vandecasteele et al., 2001; Nohria et al., 2003; Shin et al., 2007; Carev et al., 2010).

PDE4s have high affinity for cAMP, they are expressed in inflammatory cells such as T and B lymphocytes, eosinophils, neutrophils, airway epithelial cells and endothelial cells (Tenor et al., 1995a,b,c), cardiovascular tissues, and smooth muscles. PDE4 inhibitors have been developed for the treatment of asthma and COPD (Essayan, 2001). Rolipram, a highly selective first generation PDE4 inhibitor, has been used for many years as a research tool to investigate the role of PDE4. Rolipram inhibits neutrophilic and eosinophilic inflammation; it proved to be an effective antidepressant, but side effects such as nausea and gastro-intestinal disturbance terminated its clinical development (Scott et al., 1991). Roflumilast was beneficial, as assessed by improvement in lung function, even when added to a long acting $\beta_{2}$ agonist or a long acting inhaled antimuscarinic (O’Byrne and Gauvreau, 2009).

PDE5 has a higher affinity for cGMP and was identified in rat platelets (Hamet and Coquil, 1978; Coquil et al., 1980) and rat lung (Francis et al., 1980; Francis and Corbin, 1988). It is known to be abundant in smooth muscle cells (Moncada and Martin, 1993) and high expression levels have been found in pulmonary vascular 


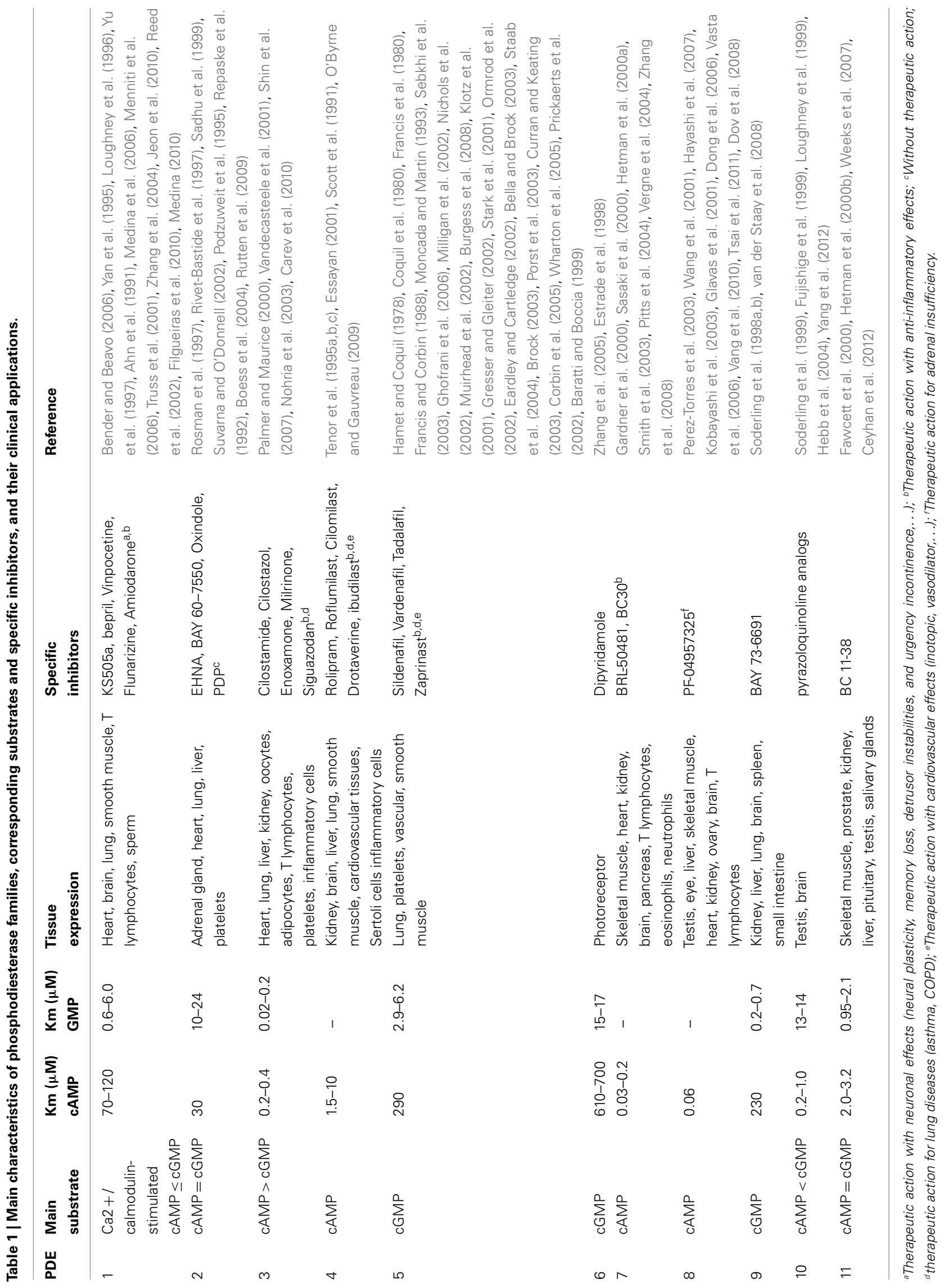


smooth muscle, bronchial blood vessels, and airway smooth muscle (Francis et al., 1980; Francis and Corbin, 1988). Recent data have shown that PDE5 may modulate pressure-induced cardiac hypertrophy and fibrosis (Sebkhi et al., 2003). Several compounds that potently inhibit PDE5 have been synthesized recently, and three of these are currently in clinical use for male erectile dysfunction (Figure 2). Sildenafil (Viagra; Pfizer Inc., USA), the first compound of this class to be marketed, provides well-tolerated pharmacotherapy for erectile dysfunction (Milligan et al., 2002; Muirhead et al., 2002; Nichols et al., 2002; Ghofrani et al., 2006; Burgess et al., 2008). Two newer selective PDE5 inhibitors, vardenafil (Levitra; GlaxoSmithKline, UK; Klotz et al., 2001; Stark et al., 2001; Gresser and Gleiter, 2002; Ormrod et al., 2002), and taladafil (Cialis; Eli Lilly, US; Eardley and Cartledge, 2002; Bella and Brock, 2003; Brock, 2003; Curran and Keating, 2003; Porst et al., 2003; Staab et al., 2004) have the same mechanism of action, as they specifically bind to the catalytic site of the enzyme catalyzing the breakdown to $5^{\prime}$-GMP of cGMP, the second messenger of the nitric oxide (NO) pathway in vascular smooth muscle cells (Moncada and Martin, 1993). Sildenafil (under the tradename Revatio) and taladafil (under the tradename Adcirca) have also been approved for the treatment of ailments related to smooth muscle tissues, such as pulmonary arterial hypertension (Sebkhi et al., 2003; Corbin et al., 2005; Wharton et al., 2005). It has been reported that sildenafil and vardenafil raise hippocampal cGMP levels and improve memory in aged rats (Prickaerts et al., 2002) and mice (Baratti and Boccia, 1999).

PDE6s display high affinity for cGMP and are expressed in the photoreceptor outer segments of the mammalian retina, in which they mediate transduction of the light signal into an electrical signal (Zhang et al., 2005). Dipyridamole has been described to be a very potent cGMP-specific PDE inhibitor of visual transduction by cGMP accumulation (Estrade et al., 1998).

PDE7s are characterized by their high affinity and selectivity for cAMP as a substrate (Gardner et al., 2000; Hetman et al., 2000a; Sasaki et al., 2000; Smith et al., 2003; Pitts et al., 2004; Vergne et al., 2004; Zhang et al., 2008). Expression is abundant in T cells, eosinophils and neutrophils, epithelial cells, vascular smooth muscle cells, and lung fibroblasts (Smith et al., 2003). Several distinct PDE7 inhibitors have been reported (Pitts et al., 2004; Vergne et al., 2004). As PDE7 is simultaneously expressed in inflammatory cells and in the brain highlights the potential role of PDE7 as drug target for neuroinflammation. It has been shown that selective PDE7 inhibition or dual PDE4/7 inhibition may provide a novel therapeutic approach for the treatment of chronic lymphocytic leukemia (CLL) by enhancing killing and increasing specificity for CLL cells (Zhang et al., 2008).

PDE8s are cAMP specific, widely distributed in various tissues (Glavas et al., 2001; Wang et al., 2001; Kobayashi et al., 2003; Perez-Torres et al., 2003; Dong et al., 2006; Hayashi et al., 2007) and abundant in testis (Vasta et al., 2006). The company Pfizer reported on a small molecule called PF-04957325 that selectively inhibits PDE8 at very low doses (Vang et al., 2010). PDE8-selective inhibitors might be used to correct adrenal insufficiency, and a PDE8 activator might be used to treat Cushing's syndrome (Tsai et al., 2011). It has also been shown that inhibiting PDE8 potentiates the biphasic insulin response to glucose (Dov et al., 2008).

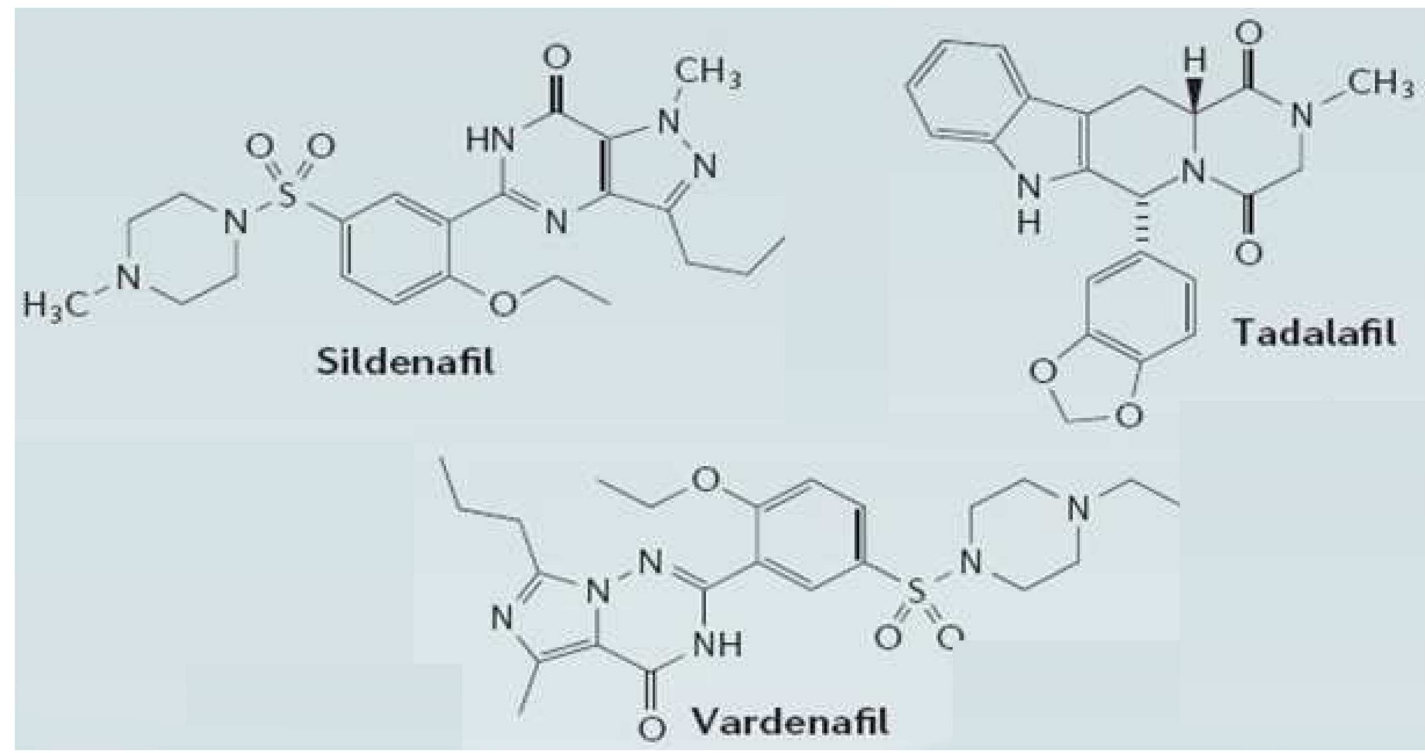

FIGURE 2 | Structures of the three clinically approved phosphodiesterase type $\mathbf{5}$ inhibitors. Sildenafil, vardenafil, and tadalafil have been approved for treatment of erectile dysfunction. Sildenafil and taladafil have also been approved as a treatment for pulmonary arterial hypertension. Sildenafil citrate is designated chemically as 1-[[3-(6,7-dihydro-1-methyl-7-oxo-3-propyl1 Hpyrazolo[4,3-d]pyrimidin-5-yl)-4-ethoxyphenyl]sulfonyl]-4-methylpiperazine citrate. Vardenafil $\mathrm{HCl}$ is designated chemically as piperazine, 1-[[3-(1,4-dihydro-5-methyl-4-oxo-7-propylimidazo[5, 1-f][1,2,4]triazin-2-yl)-4ethoxyphenyl]sulfonyl]-4-ethyl-, monohydrochloride. Taladafil is designated chemically as pyrazino[1',2':1,6]pyrido[3,4-b]indole-1,4-dione,6-(1,3benzodioxol-5-yl)-2,3,6,7,12,12a-hexahydro-2-methyl-, $(6 \mathrm{R}, 12 \mathrm{aR})$-. 
PDE9 is one of the most recently discovered PDE families. It has a very high affinity for cGMP and it is expressed in a variety of tissues (Soderling et al., 1998a,b). Compared to the other cGMP-specific PDEs, PDE9 apparently lacks the non-catalytic cGMP-binding domain present in the cGMP-specific PDE5 and PDE6 and also in the dually specific PDE2. BAY 73-6691, acting as a PDE inhibitor selective for the PDE9A subtype, is a drug developed by Bayer for the treatment of Alzheimer's disease (van der Staay et al., 2008).

PDE10 was isolated and characterized as a dual-substrate gene family distributed in fetal lungs and brain (Fujishige et al., 1999; Loughney et al., 1999; Soderling et al., 1999). The finding that striatal PDE10 mRNA and protein levels have been found to be reduced in Huntington's disease (Hebb et al., 2004) would impact on the development of PDE10 agonists. Based on their high expression levels in the brain, PDE10s have become a target for central nervous system research, especially concerning cognitive deficits related to schizophrenia and psychotic statuses. A series of pyrazoloquinoline analogs have been synthesized and shown to bind with high affinity to PDE10 (Yang et al., 2012).

PDE11 are characterized by their high affinity for both cAMP and cGMP, although kinetic characteristics for the variants are different (Fawcett et al., 2000; Hetman et al., 2000b; Weeks et al., 2007). BC 11-38 is a recently identified potent and selective PDE11 inhibitor $\left(\mathrm{IC}_{50}=0.28 \mu \mathrm{M}\right)$ with potential application for adrenal insufficiency (Ceyhan et al., 2012).

\section{PDE INHIBITORS AS POTENTIAL TOOLS IN THE TREATMENT OF CYSTIC FIBROSIS}

As an important second messenger signaling molecule, cAMP controls a wide variety of eukaryotic and prokaryotic responses to extracellular cues (Antoni, 2000). As CF is characterized by a defective cAMP-dependent chloride conductance in epithelial cells, it could be expected that modulating intracellular levels of the second messenger would bring beneficial therapeutic effects for patients with $\mathrm{CF}$.

\section{NON-SELECTIVE PDE INHIBITORS}

Non-specific PDE inhibitors such as IBMX, theophylline, and DPMX (7-methyl-1,3-dipropylxanthine) have been shown to activate normal and mutated CFTR chloride channels in epithelia (Chappe et al., 1998). Due to impact on the cAMP pathway and activity at low concentrations, studies have looked at the effect of methylxanthines on the CAMP activated CFTR channel. It has been reported that IBMX increases CFTR chloride current in Xenopus oocytes expressing F508del-CFTR (Drumm et al., 1991). In nasal bronchial epithelial tissues expressing the mutant F508delCFTR, treatment with IBMX associated with a potent adenylate cyclase agonist, forskolin was unable to stimulate chloride efflux (Grubb et al., 1993). However, stably transfected F508delCFTR cells (Haws et al., 1996) showed a sevenfold increase in cAMP levels following IBMX treatment but not after cyclopentyl1,3-dipropylxanthine (CPX), another non-specific PDE inhibitor. Interestingly both IBMX and CPX potentiated the effect of forskolin on CFTR-mediated efflux of ${ }^{125}$ I by 2.5 -fold (Haws et al., 1996). A potentiation by IBMX of prostaglandin E (PGE)-induced bicarbonate secretion has been reported in the rat duodenum in vivo (Takeuchi et al., 1997; Aoi et al., 2004).

\section{SELECTIVE PDE INHIBITORS}

PDE inhibitors increase cAMP by inhibiting one or more enzymes involved in cAMP degradation. Cyclic AMP-activated PKA mediates phosphorylation of CFTR and increases the open probability of the CFTR channel. PDE3 inhibitors, amrinone, and milrinone, also cause vasodilation, which may be beneficial for CF airways. Drumm et al. showed that inhibiting PDE had a larger effect on CFTR activation than have adenylate cyclase stimulants (Kelley et al., 1995). Using airway epithelial cell lines expressing wildtype CFTR, Calu-3, and 16HBE cells, it has been found that, at $100 \mu \mathrm{M}$ concentrations, milrinone, or amrinone applied in the absence of adenylate cyclase activators, stimulate chloride efflux by 13.7-fold (Kelley et al., 1995). No effect on chloride efflux was found under stimulation with IBMX, rolipram, or dipyridamole. The increase of channel efflux by PDE3 inhibitor, amrinone, or milrinone, was not associated with a significant rise in cAMP concentrations but it was inhibited by protein kinase A inhibitors (H-8 and Rp-cAMPS), suggesting that it might work through a more distal signal. Kelley et al. (1996) also looked at endogenous CFTR in transformed nasal polyp tissue of patients homozygous for F508del (CF-T43). They found that, when administered in the presence of a $\beta$-agonist (isoproterenol) and protein kinase $A$ activator, milrinone, and amrinone, at $100 \mu \mathrm{M}$ concentrations, increased chloride efflux by $19-61 \%$ from baseline. Mice homozygous for F508del-CFTR were administered with a combination of milrinone $(100 \mu \mathrm{M})$ and forskolin $(10 \mu \mathrm{M}$; Kelley et al., 1997). This combination of drugs resulted in an increased magnitude of the nasal potential difference. The implications of this study are exciting; but the effect was confirmed in mice but not in humans (Smith et al., 1999).

It has been shown that CFTR has a major role in the regulation of duodenal bicarbonate secretion (Hogan et al., 1997). Furthermore, O'Grady et al. (2002) showed that both PDE1 and PDE3 are involved in the activation of CFTR in T84 cells and human colonic epithelial cells. Hayashi et al. (2007) suggested that PDE1 and PDE3 are involved in the regulation of duodenal bicarbonate secretion and that the response to PGE2 is associated with both PDE1 and PDE3, while the response to NO is mainly modulated by PDE1 (Hayashi et al., 2007). McPherson et al. (1999) showed that a selective cyclic nucleotide PDE5 inhibitor partially corrected defective L-adrenergic stimulation of mucin secretion in CFTR antibody-inhibited submandibular cells. The PDE5 inhibitor did not increase cAMP levels, nor did it potentiate isoproterenolinduced cAMP rise (McPherson et al., 1999). Of note, Dormer et al. (2005) demonstrated that the PDE5 inhibitor sildenafil also acts as a pharmacological chaperone. Because sildenafil is approved for clinical use, they speculated that their data might speed up the development of new therapies for CF (Dormer et al., 2005).

\section{COMPARISON OF THE PDE5 INHIBITORS}

There are distinct differences between the three clinically approved PDE5 inhibitors, sildenafil, vardenafil, and tadalafil, regarding their selectivity and specificity for PDE inhibition, with consequences on safety profile but also on biopharmaceutic and 
pharmacokinetic disparities that largely affect efficacy of the compounds (Klotz et al., 2001; Gresser and Gleiter, 2002; Milligan et al., 2002; Muirhead et al., 2002; Nichols et al., 2002; Burgess et al., 2008). Sildenafil and vardenafil are very similar in terms of chemical structure, whereas tadalafil, with a methyldione structure, differs markedly (Figure 2). These chemical properties are also reflected in similarities and dissimilarities of their clinical pharmacokinetics.

PDE5 inhibitors are rapidly absorbed after oral administration, with peak concentrations reached slightly earlier for vardenafil compared to sildenafil and tadalafil (Klotz et al., 2001; Gresser and Gleiter, 2002; Milligan et al., 2002; Muirhead et al., 2002; Nichols et al., 2002; Burgess et al., 2008). Although no clear concentrationeffect relationships have been established for any of the three PDE5 inhibitors, rapid absorption is considered essential for a rapid onset of efficacy. Administration of a high-fat meal had no significant effect on the rate and extent of absorption of tadalafil but decreased the rate of absorption for sildenafil and vardenafil. All three drugs are lipophilic and have a volume of distribution larger than the volume of total body water, indicating tissue uptake and binding. Furthermore, the three compounds are highly protein bound, with free plasma concentration fractions of only $4-6 \%$.

The major route of elimination for all PDE5 inhibitors is hepatic metabolism, with renal excretion of unchanged drug accounting for $1 \%$ or less of the elimination pathways. Based on their relatively high systemic clearance after intravenous administration, sildenafil, and vardenafil can be classified as nonrestrictively cleared drugs with intermediate to high hepatic extraction ratio. The relatively comparable distribution volumes together with the substantial differences in systemic clearance among the PDE5 inhibitors result in distinct differences of the elimination half-life, $3-5 \mathrm{~h}$ for sildenafil and vardenafil compared to $17.5 \mathrm{~h}$ for tadalafil. Tadalafil, however, has been detected in plasma even 5 days after oral administration, in line with its long half-life. This suggests the possibility of accumulation if taken regularly and in short intervals, which may result in an increased risk of side effects with excessive use.

PDE5 INHIBITORS FOR THE TREATMENT OF CYSTIC FIBROSIS So far, many efforts have been focused on CFTR pharmacotherapy to target the abnormal protein pharmacologically by various approaches such as direct correction of stop codon mutations, CFTR channel activation, or trafficking defects. High-throughput screening has been used to identify molecules that increase F508del-CFTR activity (Pedemonte et al., 2005; Van Goor et al., 2006; Carlile et al., 2007). Such molecules have been categorized according to whether they improve the folding/cellular processing defect (correctors) or increase the responsiveness of F508delCFTR channels already present in the membrane to cAMP activation (potentiators). Sildenafil has been initially shown to correct F508del-CFTR processing when used at supratherapeutic doses (Dormer et al., 2005).

\section{PDE5 INIBITORS CORRECT TRANSEPITHELIAL CHLORIDE TRANSPORT IN CYSTIC FIBROSIS: PARENTERAL ADMINISTRATION}

To test the hypothesis that PDE5 inhibitors sildenafil, vardenafil, and taladafil, when applied at therapeutic doses, are able to restore transepithelial ion transport abnormalities of the F508del-CFTR protein, we have conducted experimental studies (Lubamba et al., 2008, 2011) in CF mice homozygous for the F508del mutation (van Doorninck et al., 1995) and in their corresponding wildtype homozygous normal mice. The F508del-CFTR mouse model has been chosen because F508del is the most common and one of the most severe CF mutations and because the mouse model recapitulates, although with different degrees of severity in the different systems, the human disease phenotype. Epithelia of the F508del-CF mouse model are characterized by defective electrolyte transport, and Pseudomonas aeruginosa lipopolysaccharide (LPS) exposure mimics several aspects of CF airway epithelial inflammation such as increased pro-inflammatory cytokines, most notably interleukin (IL)-8, IL-6, and Tumor Necrosis Factor (TNF)- $\alpha$, and the predominant neutrophil infiltration.

In our protocols, CFTR function has been assessed in vivo by measuring the transepithelial nasal potential difference, a diagnostic technique that has been more recently used as an index of therapeutic efficacy in novel fundamental therapies, either in animal models (Lubamba et al., 2008, 2009, 2011) or in CF patients (Sermet-Gaudelus et al., 2010; Leonard et al., 2012a,b). Our results provide clear evidence that intraperitoneal injection of PDE5 inhibitors (Figure 3), at therapeutic doses, to F508delCF mice interact with CFTR, propping open the mutant protein to allow a normal flow of chloride ions across the epithelium of nasal mucosa, thereby restoring the decreased or even abolished CFTR-dependent chloride transport (Lubamba et al., 2008). In F508del mice, but not in cftr knockout mice, the chloride conductance, evaluated by perfusing the nasal mucosa with a chloride-free solution in the presence of amiloride (to inhibit sodium entry through the epithelial sodium channel ENaC) and with forskolin, is corrected $1 \mathrm{~h}$ after a single sildenafil administration (Figure 4A). A more prolonged effect, persisting for at least $24 \mathrm{~h}$, is observed with vardenafil (Figure 4B). Moreover, vardenafil, but not sildenafil, is able to stimulate chloride transport associated with normal wild-type CFTR protein (Figure 4B). The forskolin response is increased after treatment with sildenafil or vardenafil in wild-type and in F508del mutant animals. In F508del mice, the chloride conductance in the presence of $200 \mu \mathrm{M}$ DIDS (4-4'-diisothiocyanostilbene-2,2' -disulphonic acid), an inhibitor of alternative chloride channels, was much higher after sildenafil injection than following placebo treatment. This observation, in addition to the finding that no activating effect of chloride transport can be observed after treatment with PDE5 inhibitors in animals knockout for the CFTR protein, indicates that the action of PDE5 inhibitors on chloride transport across the respiratory epithelium involves F508del-CFTR and not a CFTR bypass channel. No effect on the sodium conductance was detected in any group of animals.

\section{PDE5 INHIBITORS CORRECT TRANSEPITHELIAL CHLORIDE TRANSPORT IN CYSTIC FIBROSIS: INHALATIONAL ADMINISTRATION}

More recently, animal studies have shown that nebulizing F508delCF mice with any of the PDE5 inhibitors sildenafil, vardenafil, or taladafil led to correction of the nasal chloride transport (Lubamba et al., 2011). Correction is largest with taladafil and smallest, but still highly significant, with sildenafil. The effect of vardenafil, but 


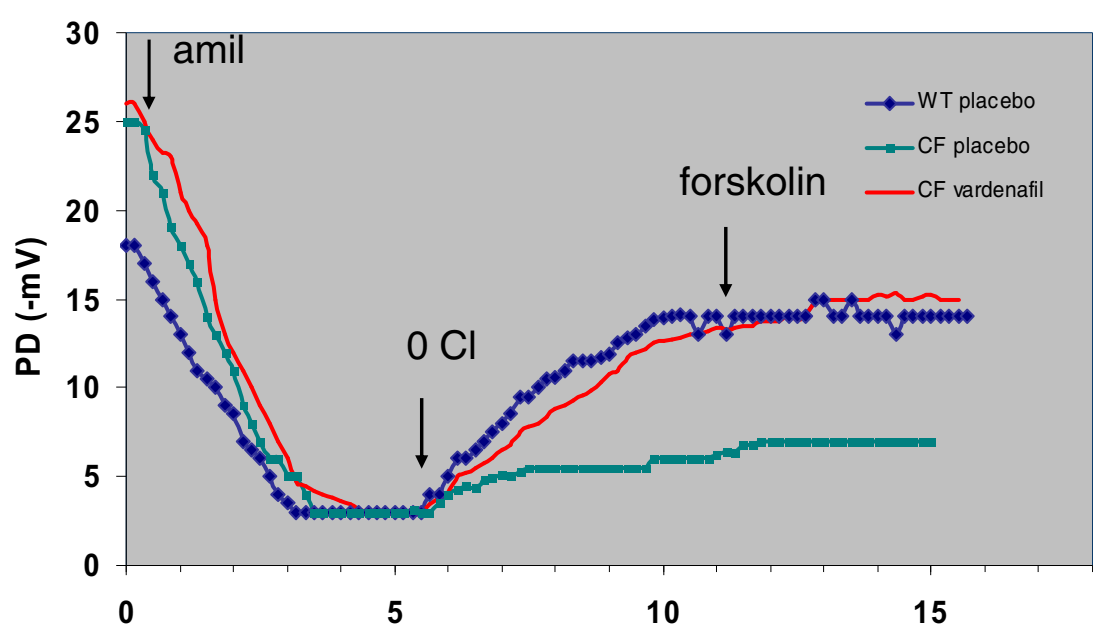

FIGURE 3 | Representative tracings of nasal potential difference (PD) measurements in wild-type (WT) and F508del-CF (CF) mice $24 \mathrm{~h}$ after placebo (saline) or vardenafil (single i.p. dose of $0.14 \mathrm{mg} / \mathbf{k g}$ body weight). Tracings show sequential response of the nasal surface to perfusion successively with basal solution, basal solution with $10^{-4} \mathrm{M}$ amiloride (amil), chloride-free solution plus amiloride $(0 \mathrm{Cl})$, and chloride-free solution with amiloride plus 10-5 M forskolin (forskolin). Arrows indicate change of solutions. As illustrated, basal values and amiloride response are not influenced by vardenafil treatment. However, chloride secretion (difference between values obtained at the end of the test and the end of the amiloride phase) is restored in CF animals and the effect lasts at least $24 \mathrm{~h}$ after vardenafil treatment (Lubamba et al., 2008). not sildenafil, lasts at least $8 \mathrm{~h}$ after a single inhaled therapeutic dose. These findings clearly identify the inhalational route as a potential therapy for PDE5 inhibitors in CF which is clinically relevant taking into account the cost of systemic side effects of the drugs (Dalby and Suman, 2003).

Consistent with our results, it has recently been demonstrated that the inhalation route of administration for vardenafil is associated with an acceptable safety profile. Apart from brief coughing on inspiration, no clinically significant changes in blood pressure or heart rate and no serious adverse events were recorded (Berry et al., 2009). Inhalation drug therapy has several potential advantages over oral and intravenous routes, including rapid onset of pharmacological action, minimized systemic adverse effects and reduced effective drug doses compared to the same drug delivered orally (Berry et al., 2009); this greatly highlights the impact of our work for translational science.

\section{PDE5 INHIBITORS ATTENUATE EXAGGERATED INFLAMMATORY RESPONSES IN CYSTIC FIBROSIS}

Another important goal of mutation-specific CF treatment is attenuation of exaggerated lung inflammatory responses (Legssyer et al., 2006; Gavilanes et al., 2009; Meyer et al., 2009). As lung inflammation plays a major role in morbi-mortality in CF, identifying a therapeutic strategy that combines ability to correct the basic ion transport defect and to reduce dysregulated inflammatory responses is very exciting and promising. It has been reported that sildenafil reduces neutrophil lung infiltration in murine airways infected with $P$. aeruginosa (Poschet et al., 2007). In addition, toxicological studies have shown that sildenafil pretreatment attenuates acrolein-triggered airway inflammation associated with mucin overproduction (Wang et al., 2009).

More recently, we have found that vardenafil, selected as a representative PDE5 inhibitor for its longer-lasting CFTR activating effect, modulates the vicious circle of lung inflammation and attenuates the expression of pro-inflammatory cytokines and chemokines and cell infiltrates in the bronchoalveolar lavage (BAL) of CF and wild-type mice (Lubamba et al., 2012b). Intraperitoneal administration of a single pharmacological dose $(0.14 \mathrm{mg} / \mathrm{kg}$ body weight) of vardenafil is followed by a reducing response in cell infiltrate and in the biosynthesis of several biomarkers of the inflammatory response. Most notably, levels of CCL-2 (chemokine C-C motif ligand), a cytokine playing a key role in the contribution of macrophages in the inflammatory response (Meyer et al., 2009), are significantly reduced in the BAL fluid after vardenafil treatment, particularly in CF animals (Figure 5).

The mechanism of action of vardenafil as an anti-inflammatory agent in CF as well as the target-effector cells involved in these responses are under investigation by our group. Altogether, our data indicate that PDE5 inhibitors have a strong therapeutic potential for treating CF. A clinical trial aimed at investigating the safety and efficacy of sildenafil in CF lung disease is currently listed on www.clinicaltrials.gov (NCT00659529).

\section{PERSPECTIVE FUTURE RESEARCH}

Beside the clinical application for erectile dysfunction and for pulmonary arterial hypertension, a growing body of research has confirmed putative beneficial effects of PDE5 inhibitors in CF. Recent studies conducted in F508del and in wild-type CFTR expressing Xenopus laevis oocytes and human bronchial epithelial cells have indicated that sildenafil acts as a corrector and as a potentiator of the mutant and wild-type protein by distinct cGMP-independent and cGMP-dependent mechanisms respectively (Leier et al., 2012). While in $X$. laevis oocytes, low $(1.5 \mu \mathrm{mol} / \mathrm{l})$ doses were required to rescue F508del-CFTR function and cell membrane localization, suprapharmacological doses roughly 120 times larger than those commonly used for the treatment of erectile dysfunction 


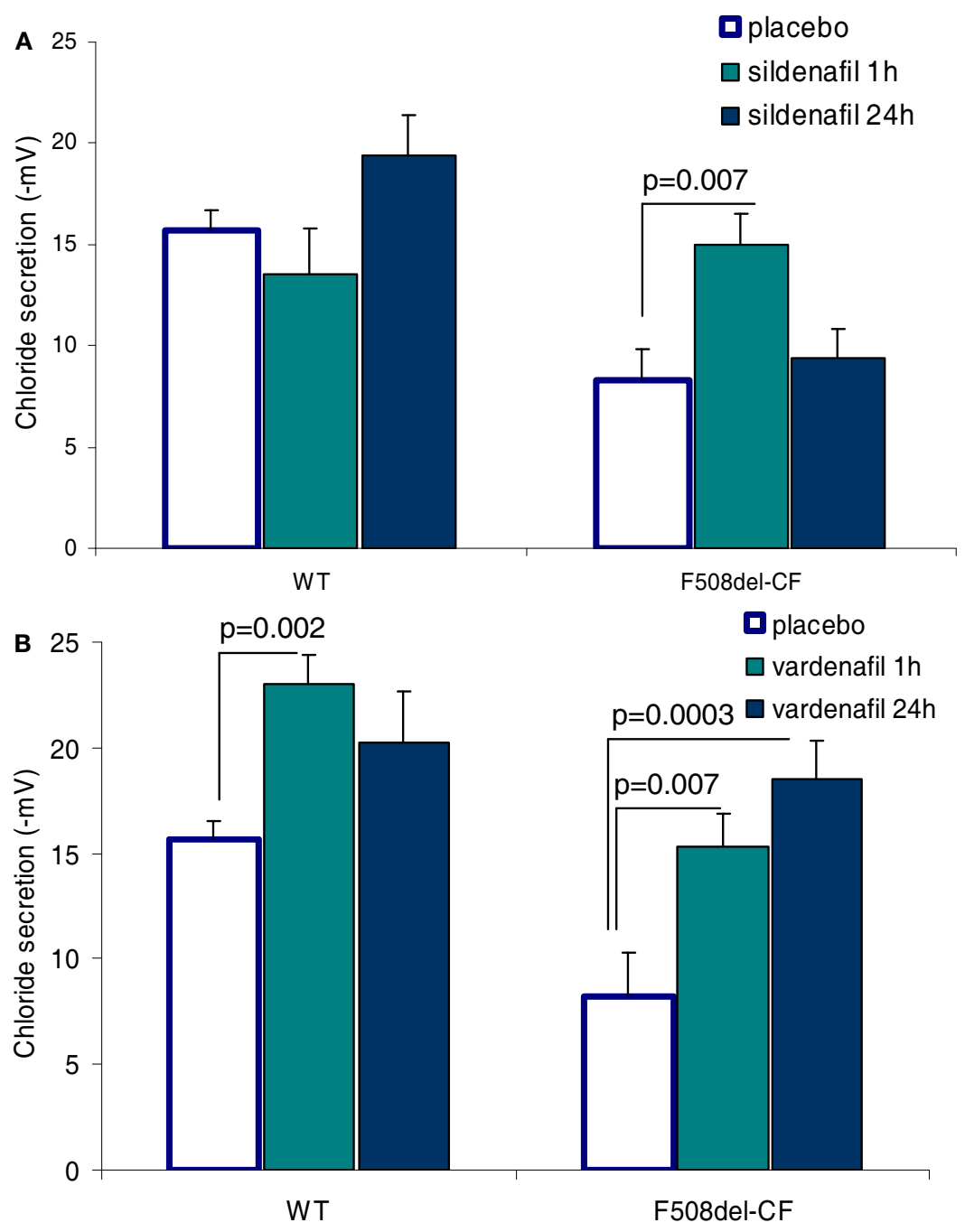

FIGURE 4 | Effect of parenteral (i.p.) administration of sildenafil (A: $0.7 \mathrm{mg} / \mathrm{kg}$ body weight) and of vardenafil ( $B ; 0.14 \mathrm{mg} / \mathrm{kg}$ body weight) on CFTR-dependent chloride secretion assessed by means of the nasal potential difference (PD) in wild-type (WT) and F508del-CF mice.
Vardenafil stimulates chloride secretion of the wild-type CFTR. The correcting effect of vardenafil lasts at least $24 \mathrm{~h}$. Data are expressed as mean \pm SEM of 14-15 placebo treated animals and six animals treated with PDE5 inhibitors (Lubamba et al., 2008). were needed to achieve the same correcting effects in human bronchial epithelial cells (Leier et al., 2012). In this perspective, adverse drug effects including flushing, headache, and other cardiovascular effects could compromise the potential use of PDE5 inhibitors in CF.

Attempts should therefore be made either to achieve chemical modifications of PDE5 inhibitors with enhanced biochemical potency and selectivity or to allow inhalational therapy of the drugs. A structural analog of sildenafil, KM11060, designated chemically as 7-chloro-4-\{4-[4chlorophenyl)sulfonyl]piperazino\}quinoline, has been recently identified as a novel potent corrector of the F508del-CFTR trafficking defect (Robert et al., 2008). F508del-CFTR trafficking was partially restored and maturation of the mutant protein was significantly increased in baby hamster kidney cells treated with low doses for a short duration ( $10 \mathrm{nM}$ for $24 \mathrm{~h}$ or $10 \mu \mathrm{M}$ for $2 \mathrm{~h}$ ) of the compound (Robert et al., 2008). Since the morbi-mortality of CF is mostly related with respiratory manifestations and an acceptable safety profile with no serious adverse events was recorded when vardenafil was applied by inhalational route (Berry et al., 2009), topical airway deposition of PDE5 inhibitors (Lubamba et al., 2011) should be considered in future human studies. As a matter of fact, inhalation drug therapy has several potential advantages over oral and intravenous routes, including rapid onset of pharmacological action, minimized systemic adverse effects, and reduced effective drug doses compared to the same drug delivered orally (Dalby and Suman, 2003).

\section{CONCLUSION}

Despite great advances in the understanding of the genetics and pathophysiology of the disease, there is still no cure for CF and existing therapies have mainly aimed at alleviating clinical 
A

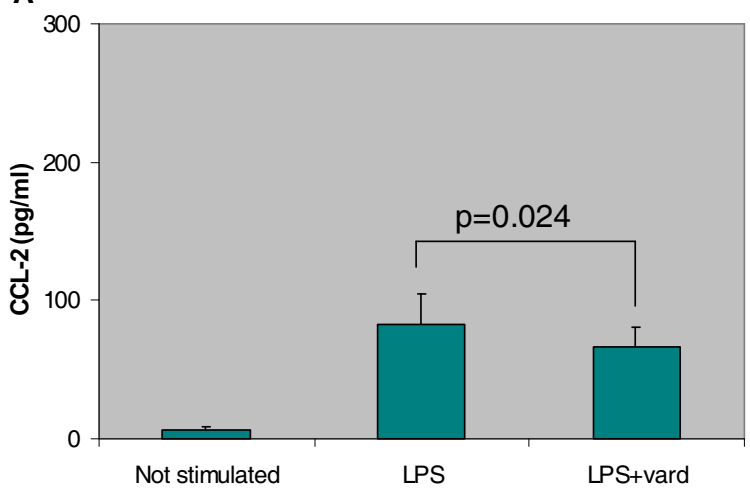

FIGURE 5 | Anti-inflammatory effect of in vivo treatment, by i.p. injection, of a single therapeutic dose of vardenafil (vard) to wild-type (A) and F508del-CF (B) mice on the inflammatory response induced by
B

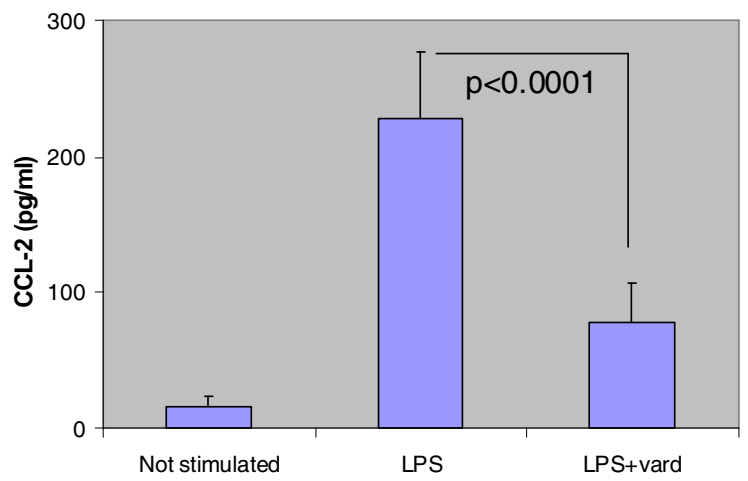

lipopolyssaccharide from $\boldsymbol{P}$ aeruginosa (LPS). Biosynthesis of CCL-2 is significantly reduced in the bronchoalveolar lavage of vardenafil-treated CF and non-CF animals (Lubamba et al., 2012b). symptoms. Recent experimental evidence has highlighted the potential of PDE5 inhibitors, sildenafil, vardenafil, and taladafil, as therapeutic agents in CF. As the drugs are able to correct the basic transepithelial ion transport abnormalities and to limit exaggerated inflammatory responses related to the presence of F508del-CFTR protein, they can represent promising compounds for fundamental pharmacotherapy in CF. Since the drugs are in clinical use, therapeutic approaches to address F508del-CFTR defects by PDE5 inhibitors can be considered as a "low-hanging fruit" strategy in the drug discovery tree which could speed up their development as CF therapeutics, as compared to other agents that are under investigation only for CF therapy and for which further exploratory studies are needed before being streamed toward clinical testing. In summary, CFTR correction with PDE5 inhibitors is a promising therapeutic approach based on functional correction

\section{REFERENCES}

Ahn, H. S., Foster, M., Cable, M., Pitts, B. J., and Sybertz, E. J. (1991). Ca/CaMstimulated and cGMP-specific phosphodiesterases in vascular and nonvascular tissues. Adv. Exp. Med. Biol. 308, 191-197.

Amaral, M. D. (2004). CFTR and chaperones: processing and degradation. J. Mol. Neurosci. 23, 41-48.

Antoni, F. A. (2000). Molecular diversity of cyclic AMP signalling. Front. Neuroendocrinol. 21:193. doi:10.1006/frne.1999.0193

Aoi, M., Aihara, E., Nakashima, M., and Takeuchi, K. (2004). Participation of prostaglandin $\mathrm{E}$ receptor EP4 subtype in duodenal bicarbonate secretion in rats. Am. J. Physiol. Gastrointest. Liver Physiol. 287, G96-G103.

Baratti, C. M., and Boccia, M. M. (1999). Effects of sildenafil on long-term retention of an inhibitory avoidance response in mice. Behav. Pharmacol. 10, 731-737.
Barnes, P. J. (2003a). Theophylline: new perspectives for an old drug. Am. J. Respir. Crit. Care Med. 167, 813-818.

Barnes, P. J. (2003b). Therapy of chronic obstructive pulmonary disease. Pharmacol. Ther. 97, 87-94. chronic obstructive pulmonary disease: new horizons. Proc. Am. Tho rac. Soc. 2, 334-339.

Barnes, P. J., and Stockley, R. A. (2005). COPD: current therapeutic interventions and future approaches. Eur. Respir. J. 25, 1084-1106.

Beavo, J. A., Rogers, N. L., Crofford, O. B., Hardman, J. G., Sutherland, E. W., and Newman, E. V. (1970). Effects of xanthine derivatives on lipolysis and on adenosine $3^{\prime}, 5^{\prime}$-monophosphate phosphodiesterase activity. Mol. Pharmacol. 6, 597-603.

Bella, A. J., and Brock, G. B. (2003). Tadalafil in the treatment of erectile dysfunction. Curr. Urol. Rep. 4, 472-478.
Barnes, P. J. (2003c). Theophylline in

of F508del-CFTR activity and on a possible anti-inflammatory action in F508del mice. The effects of these compounds on other $\mathrm{CF}$ mutation classes remain to be assessed. The routes for administration should also be further explored, and aerosolized delivery of PDE5 inhibitors should be considered.

\section{ACKNOWLEDGMENTS}

$\mathrm{SN}$ is a postdoctoral fellow with the Fonds Spéciaux de Recherche (FSR; Université catholique de Louvain) and Marie Curie Actions of the European Commission. TL is an associate researcher with the Fonds de la Recherche Scientifique Médicale (FRSM). Supported by grants of the French CF Association, Vaincre la Mucoviscidose; the FRSM; the FSR, and the Foundation St Luc (St Luc University Hospital and Universite catholique de Louvain). The authors thank Bob Lubamba for technical assistance.

Bender, A. T., and Beavo, J. A. (2006). Cyclic nucleotide phosphodiesterases: molecular regulation to clinical use. Pharmacol. Rev. 58, 488-520.

Berry, B., Altman, P., Rowe, J., and Vaisman, T. (2009). Comparison of pharmacokinetics of vardenafil administered using an ultrasonic nebulizer for inhalation versus a single 10-mg oral tablet. J. Sex. Med. PMID: 19656275. [Epub ahead of print].

Bhatt-Mehta, V., and Schumacher, R. E. (2003). Treatment of apnea of prematurity. Paediatr. Drugs 5, 195-210.

Boess, F. G., Hendrix, M., van der Staay, F. J., Erb, C., Schreiber, R., van Staveren, W., de Vente, J., Prickaerts, J., Blokland, A., and Koenig, G. (2004). Inhibition of phosphodiesterase 2 increases neuronal cGMP, synaptic plasticity and memory performance. Neuropharmacology 47, 1081-1092.
Brock, G. B. (2003). Tadalafil: a new agent for erectile dysfunction. Can. J. Urol. 10(Suppl. 1), 17-22.

Burgess, G., Hoogkamer, H., Collings, L., and Dingemanse, J. (2008). Mutual pharmacokinetic interactions between steady-state bosentan and sildenafil. Eur. J. Clin. Pharmacol. 64, 43-50.

Carev, M., Bulat, C., Karanovic, N., Lojpur, M., Jercic, A., Nenadic, D., Marovih, Z., Husedzinovic, I., and Letica, D. (2010). Combined usage of inhaled and intravenous milrinone in pulmonary hypertension after heart valve surgery. Coll. Antropol. 34, 1113-1117.

Carlile, G. W., Robert, R., Zhang, D., Teske, K. A., Luo, Y., Hanrahan, J. W., and Thomas, D. Y. (2007). Correctors of protein trafficking defects identified by a novel high-throughput screening assay. Chembiochem 8, 1012-1020. 
Ceyhan, O., Birsoy, K., and Hoffman, C. S. (2012). Identification of biologically active PDE11-selective inhibitors using a yeast-based highthroughput screen. Chem. Biol. 19, 155-163.

Chappe, V., Mettey, Y., Vierfond, J. M., Hanrahan, J. W., Gola, M., Verrier, B., and Becq, F. (1998). Structural basis for specificity and potency of xanthine derivatives as activators of the CFTR chloride channel. Br. J. Pharmacol. 123, 683-693.

Cheung, W. Y. (1970). Cyclic nucleotide phosphodiesterase. Adv. Biochem. Psychopharmacol. 3, 51-65.

Conti, M. (2000). Phosphodiesterases and cyclic nucleotide signaling in endocrine cells. Mol. Endocrinol. 14, 1317-1327.

Coquil, J. F., Franks, D. J., Wells, J. N., Dupuis, M., and Hamet, P. (1980). Characteristics of a new binding protein distinct from the kinase for guanosine $3^{\prime}: 5^{\prime}$-monophosphate in rat platelets. Biochim. Biophys. Acta 631, 148-165.

Corbin, J. D., Beasley, A., Blount, M. A., and Francis, S. H. (2005). High lung PDE5: a strong basis for treating pulmonary hypertension with PDE5 inhibitors. Biochem. Biophys. Res. Commun. 334, 930-938.

Curran, M., and Keating, G. (2003). Tadalafil. Drugs 63, 2203-2212; discussion 2213-2214.

Dalby, R., and Suman, J. (2003). Inhalation therapy: technological milestones in asthma treatment. Adv. Drug Deliv. Rev. 55, 779-791.

Davis, P. B. (2006). Cystic fibrosis since 1938. Am. J. Respir. Crit. Care Med. 173, 475-482.

Dong, H., Osmanova, V., Epstein, P. M., and Brocke, S. (2006). Phosphodiesterase 8 (PDE8) regulates chemotaxis of activated lymphocytes. Biochem. Biophys. Res. Commun. 345, 713-719.

Dormer, R. L., Harris, C. M., Clark, Z., Pereira, M. M., Doull, I. J., Norez, C., Becq, F., and McPherson, M. A. (2005). Sildenafil (Viagra) corrects DeltaF508-CFTR location in nasal epithelial cells from patients with cystic fibrosis. Thorax 60, 55-59.

Dov, A., Abramovitch, E., Warwar, N., and Nesher, R. (2008). Diminished phosphodiesterase- $8 \mathrm{~B}$ potentiates biphasic insulin response to glucose. Endocrinology 149, 741-748.

Drumm, M. L., Wilkinson, D. J., Smit, L. S., Worrell, R. T., Strong, T. V., Frizzell, R. A., Dawson, D. C., and Collins, F. S. (1991). Chloride conductance expressed by delta F508 and other mutant CFTRs in Xenopus oocytes. Science 254, 1797-1799.
Eardley, I., and Cartledge, J. (2002). Tadalafil (Cialis) for men with erectile dysfunction. Int. J. Clin. Pract. 56, 300-304.

Essayan, D. M. (2001). Cyclic nucleotide phosphodiesterases. J. Allergy Clin. Immunol. 108, 671-680.

Estrade, M., Grondin, P., Cluzel, J., Bonhomme, B., and Doly, M. (1998). Effect of a cGMP-specific phosphodiesterase inhibitor on retinal function. Eur. J. Pharmacol. 352, 157-163.

Fawcett, L., Baxendale, R., Stacey, P., McGrouther, C., Harrow, I., Soderling, S., Hetman, J., Beavo, J. A., and Phillips, S. C. (2000). Molecular cloning and characterization of a distinct human phosphodiesterase gene family: PDE11A. Proc. Natl. Acad. Sci. U.S.A. 97, 3702-3707.

Filgueiras, C. C., Krahe, T. E., and Medina, A. E. (2010). Phosphodiesterase type 1 inhibition improves learning in rats exposed to alcohol during the third trimester equivalent of human gestation. Neurosci. Lett. 473, 202-207.

Francis, S. H., and Corbin, J. D. (1988). Purification of cGMP-binding protein phosphodiesterase from rat lung. Meth. Enzymol. 159, 722-729.

Francis, S. H., Lincoln, T. M., and Corbin, J. D. (1980). Characterization of a novel cGMP binding protein from rat lung. J. Biol. Chem. 255, 620-626.

Francis, S. H., Turko, I. V., and Corbin, J. D. (2001). Cyclic nucleotide phosphodiesterases: relating structure and function. Prog. Nucleic Acid Res. Mol. Biol. 65, 1-52.

Fujishige, K., Kotera, J., Michibata, H., Yuasa, K., Takebayashi, S., Okumura, K., and Omori, K. (1999). Cloning and characterization of a novel human phosphodiesterase that hydrolyzes both cAMP and cGMP (PDE10A). J. Biol. Chem. 274, 18438-18445.

Gardner, C., Robas, N., Cawkill, D., and Fidock, M. (2000). Cloning and characterization of the human and mouse PDE7B, a novel CAMPspecific cyclic nucleotide phosphodiesterase. Biochem. Biophys. Res. Commun. 272, 186-192.

Gavilanes, X., Huaux, F., Meyer, M., Lebecque, P., Marbaix, E., Lison, D., Scholte, B., Wallemacq, P., and Leal, T. (2009). Azithromycin fails to reduce increased expression of neutrophil-related cytokines in primary-cultured epithelial cells from cystic fibrosis mice. J. Cyst. Fibros. 8, 203-210.

Ghofrani, H. A., Osterloh, I. H., and Grimminger, F. (2006). Sildenafil: from angina to erectile dysfunction to pulmonary hypertension and beyond. Nat. Rev. Drug Discov. 5 , 689-702.

Glavas, N. A., Ostenson, C., Schaefer, J. B., Vasta, V., and Beavo, J. A. (2001). $\mathrm{T}$ cell activation up-regulates cyclic nucleotide phosphodiesterases 8A1 and 7A3. Proc. Natl. Acad. Sci. U.S.A. 98, 6319-6324.

Gresser, U., and Gleiter, C. H. (2002). Erectile dysfunction: comparison of efficacy and side effects of the PDE5 inhibitors sildenafil, vardenafil and tadalafil - review of the literature. Eur. J. Med. Res. 7, 435-446.

Grubb, B., Lazarowski, E., Knowles, M., and Boucher, R. (1993). Isobutylmethylxanthine fails to stimulate chloride secretion in cystic fibrosis airway epithelia. Am. J. Respir. Cell Mol. Biol. 8, 454-460.

Guerreiro, S., Toulorge, D., Hirsch, E., Marien, M., Sokoloff, P., and Michel, P. P. (2008). Paraxanthine, the primary metabolite of caffeine, provides protection against dopaminergic cell death via stimulation of ryanodine receptor channels. Mol. Pharmacol. 74, 980-989.

Hamet, P., and Coquil, J. F. (1978). Cyclic GMP binding and cyclic GMP phosphodiesterase in rat platelets. $J$. Cyclic Nucleotide Res. 4, 281-290.

Haws, C. M., Nepomuceno, I. B. Krouse, M. E., Wakelee, H., Law, T., Xia, Y., Nguyen, H., and Wine, J. J. (1996). Delta F508-CFTR channels: kinetics, activation by forskolin, and potentiation by xanthines. Am. J. Physiol. 270, C1544-C1555.

Hayashi, M., Kita, K., Ohashi, Y., Aihara E., and Takeuchi, K. (2007). Phosphodiesterase isozymes involved in regulation of $\mathrm{HCO} 3$-secretion in isolated mouse duodenum in vitro. Biochem. Pharmacol. 74, 1507-1513.

Hebb, A. L., Robertson, H. A., and Denovan-Wright, E. M. (2004). Striatal phosphodiesterase mRNA and protein levels are reduced in Huntington's disease transgenic mice prior to the onset of motor symptoms. Neuroscience 123, 967-981.

Hetman, J. M., Soderling, S. H., Glavas, N. A., and Beavo, J. A. (2000a). Cloning and characterization of PDE7B, a cAMP-specific phosphodiesterase. Proc. Natl. Acad. Sci. U.S.A. 97, 472-476.

Hetman, J. M., Robas, N., Baxendale, R., Fidock, M., Phillips, S. C., Soderling, S. H., and Beavo, J. A. (2000b). Cloning and characterization of two splice variants of human phosphodiesterase 11A. Proc. Natl. Acad. Sci. U.S.A. 97, 12891-12895.
Hogan, D. L., Crombie, D. L., Isenberg, J. I., Svendsen, P., Schaffalitzky de Muckadell, O. B., and Ainsworth, M. A. (1997). CFTR mediates cAMP- and Ca2+-activated duodenal epithelial HCO3-secretion. Am. J. Physiol. 272, G872-G878.

Jeon, K. I., Xu, X., Aizawa, T., Lim, J. H., Jono, H., Kwon, D. S., Abe, J., Berk, B. C., Li, J. D., and Yan, C. (2010). Vinpocetine inhibits NF-kappaB-dependent inflammation via an IKK-dependent but PDE-independent mechanism. Proc. Natl. Acad. Sci. U.S.A. 107, 9795-9800.

Kelley, T. J., Al-Nakkash, L., Cotton, C. U., and Drumm, M. L. (1996). Activation of endogenous deltaF508 cystic fibrosis transmembrane conductance regulator by phosphodiesterase inhibition. J. Clin. Invest. 98 , 513-520.

Kelley, T. J., Al-Nakkash, L., and Drumm, M. L. (1995). CFTRmediated chloride permeability is regulated by type III phosphodiesterases in airway epithelial cells. Am. J. Respir. Cell Mol. Biol. 13, 657-664.

Kelley, T. J., Thomas, K., Milgram, L. J., and Drumm, M. L. (1997). In vivo activation of the cystic fibrosis transmembrane conductance regulator mutant deltaF508 in murine nasal epithelium. Proc. Natl. Acad. Sci. U.S.A. 94, 2604-2608.

Kerem, B., Rommens, J. M., Buchanan, J. A., Markiewicz, D., Cox, T. K., Chakravarti, A., Buchwald, M., and Tsui, L. C. (1989). Identification of the cystic fibrosis gene: genetic analysis. Science 245, 1073-1080.

Klotz, T., Sachse, R., Heidrich, A., Jockenhovel, F., Rohde, G., Wensing, G., Horstmann, R., and Engelmann, R. (2001). Vardenafil increases penile rigidity and tumescence in erectile dysfunction patients: a RigiScan and pharmacokinetic study. World J. Urol. 19, 32-39.

Kobayashi, T., Gamanuma, M., Sasaki, T., Yamashita, Y., Yuasa, K., Kotera, J., and Omori, K. (2003). Molecular comparison of rat cyclic nucleotide phosphodiesterase 8 family: unique expression of PDE8B in rat brain. Gene 319, 21-31.

Legssyer, R., Huaux, F., Lebacq, J., Delos, M., Marbaix, E., Lebecque, P., Lison, D., Scholte, B. J., Wallemacq, P., Leal, and T. (2006). Azithromycin reduces spontaneous and induced inflammation in deltaf508 cystic fibrosis mice. Respir. Res. 7, 134.

Leier, G., Bangel-Ruland, N., Sobczak, K., Knieper, Y., and Weber, W. M. (2012). Sildenafil acts as potentiator 
and corrector of CFTR but might be not suitable for the treatment of CF lung disease. Cell Physiol. Biochem. 29, 775-790.

Leonard, A., Lebecque, P., Dingemanse, J, and Leal, T. (2012a). A randomized placebo-controlled trial of miglustat in cystic fibrosis based on nasal potential difference. J. Cyst. Fibros. 11, 231-236.

Leonard, A., Lubamba, B., Dhooghe, B., Noël, S., Wallemacq, P., Lebecque, P., and Leal, T. (2012b). Comparative variability of nasal potential difference measurements in human and mice. Open J. Respir. Dis. 2, 43-56.

Loughney, K., Martins, T. J., Harris, E. A., Sadhu, K., Hicks, J. B., Sonnenburg, W. K., Beavo, J. A., and Ferguson, K. (1996). Isolation and characterization of cDNAs corresponding to two human calcium, calmodulinregulated, $3^{\prime}, 5^{\prime}$-cyclic nucleotide phosphodiesterases. J. Biol. Chem. 271, 796-806.

Loughney, K., Snyder, P. B., Uher, L., Rosman, G. J., Ferguson, K., and Florio, V. A. (1999). Isolation and characterization of PDE10A, a novel human $3^{\prime}, 5^{\prime}$-cyclic nucleotide phosphodiesterase. Gene 234, 109-117.

Lubamba, B., Dhooghe, B., Noël, S., and Leal, T. (2012a). Cystic fibrosis: insight into CFTR pathophysiology and pharmacotherapy. Clin. Biochem. PMID: 22698459. [Epub ahead of print].

Lubamba, B., Huaux, F., Lebacq, J., Marbaix, E., Dhooghe, B., Panin, N., Wallemacq, P., and Leal, T. (2012b). Immunomodulatory activity of vardenafil on induced lung inflammation in cystic fibrosis mice. J. Cyst. Fibros. 11, 266-273.

Lubamba, B., Lebacq, J., Lebecque, P., Vanbever, R., Leonard, A., Wallemacq, P., and Leal, T. (2009). Airway delivery of low dose miglustat normalizes nasal potential difference in F508del cystic fibrosis mice. Am. J. Respir. Crit. Care Med. 179, 1022-1028.

Lubamba, B., Lebacq, J., Reychler, G., Marbaix, E., Wallemacq, P., Lebecque, P., and Leal, T. (2011). Inhaled phosphodiesterase type 5 inhibitors restore chloride transport in cystic fibrosis mice. Eur. Respir. J. $37,72-78$.

Lubamba, B., Lecourt, H., Lebacq, J., Lebecque, P., De Jonge, H., Wallemacq, P., and Leal, T. (2008). Preclinical evidence that sildenafil and vardenafil activate chloride transport in cystic fibrosis. Am. J. Respir. Crit. Care Med. 177, 506-515.

Lukacs, G. L., Mohamed, A., Kartner, N., Chang, X. B., Riordan, J. R., and Grinstein, S. (1994). Conformational maturation of CFTR but not its mutant counterpart (delta f508) occurs in the endoplasmic reticulum and requires ATP. EMBO J. 13, 6076-6086.

McPherson, M. A., Pereira, M. M., Lloyd Mills, C., Murray, K. J., and Dormer, R. L. (1999). A cyclic nucleotide PDE5 inhibitor corrects defective mucin secretion in submandibular cells containing antibody directed against the cystic fibrosis transmembrane conductance regulator protein. FEBS Lett. 464, 48-52.

Medina, A. E. (2010). Vinpocetine as a potent antiinflammatory agent. Proc. Natl. Acad. Sci. U.S.A. 107, 9921-9922.

Medina, A. E., Krahe, T. E., and Ramoa, A. S. (2006). Restoration of neuronal plasticity by a phosphodiesterase type 1 inhibitor in a model of fetal alcohol exposure. J. Neurosci. 26, 1057-1060.

Mehats, C., Andersen, C. B., Filopanti, M., Jin, S. L., and Conti, M. (2002). Cyclic nucleotide phosphodiesterases and their role in endocrine cell signaling. Trends Endocrinol. Metab. 13, 29-35.

Menniti, F. S., Faraci, W. S., and Schmidt, C. J. (2006). Phosphodiesterases in the CNS: targets for drug development. Nat. Rev. Drug Discov. 5, 660-670.

Meyer, M., Huaux, F., Gavilanes, X., van den Brûle, S., Lebecque, P., Lo Re, S., Lison, D., Scholte, B., Wallemacq, P., and Leal, T. (2009). Azithromycin reduces exaggerated cytokine production by $\mathrm{M} 1$ alveolar macrophages in cystic fibrosis. Am. J. Respir. Cell Mol. Biol. 41, 590-602.

Milligan, P. A., Marshall, S. F., and Karlsson, M. O. (2002). A population pharmacokinetic analysis of sildenafil citrate in patients with erectile dysfunction. Br. J. Clin. Pharmacol. 53(Suppl. 1), 45S-52S.

Moncada, S., and Martin, J. F. (1993). Evolution of nitric oxide. Lancet 341 , 1511.

Muirhead, G. J., Rance, D. J., Walker, D. K., and Wastall, P. (2002). Comparative human pharmacokinetics and metabolism of single-dose oral and intravenous sildenafil. Br. J. Clin. Pharmacol. 53(Suppl. 1), 13S-20S.

Muller, C. E., and Jacobson, K. A. (2011). Xanthines as adenosine receptor antagonists. Handb. Exp. Pharmacol. 200, 151-199.

Nichols, D. J., Muirhead, G. J., and Harness, J. A. (2002). Pharmacokinetics of sildenafil after single oral doses in healthy male subjects: absolute bioavailability, food effects and dose proportionality. Br. J. Clin. Pharmacol. 53(Suppl. 1), 5S-12S.

Nohria, A., Tsang, S. W., Fang, J. C. Lewis, E. F., Jarcho, J. A., Mudge, G. H., and Stevenson, L. W. (2003). Clinical assessment identifies hemodynamic profiles that predict outcomes in patients admitted with heart failure. J. Am. Coll. Cardiol. 41, 1797-1804.

O'Byrne, P. M., and Gauvreau, G. (2009). Phosphodiesterase-4 inhibition in COPD. Lancet 374, 665-667.

O'Grady, S. M., Jiang, X., Maniak, P. J., Birmachu, W., Scribner, L. R., Bulbulian, B., and Gullikson, G. W. (2002). Cyclic AMP-dependent $\mathrm{Cl}$ secretion is regulated by multiple phosphodiesterase subtypes in human colonic epithelial cells. J. Membr. Biol. 185, 137-144.

Ormrod, D., Easthope, S. E., and Figgitt, D. P. (2002). Vardenafil. Drugs Aging 19, 217-227.

Palmer, D., and Maurice, D. H. (2000). Dual expression and differential regulation of phosphodiesterase $3 \mathrm{~A}$ and phosphodiesterase $3 \mathrm{~B}$ in human vascular smooth muscle: implications for phosphodiesterase 3 inhibition in human cardiovascular tissues. Mol. Pharmacol. 58, 247-252.

Pedemonte, N., Lukacs, G. L., Du, K., Caci, E., Zegarra-Moran, O., Galietta, L. J., and Verkman, A. S. (2005). Small-molecule correctors of defective DeltaF508-CFTR cellular processing identified by highthroughput screening. J. Clin. Invest. 115, 2564-2571.

Perez-Torres, S., Cortes, R., Tolnay, M., Probst, A., Palacios, J. M. and Mengod, G. (2003). Alterations on phosphodiesterase type 7 and 8 isozyme mRNA expression in Alzheimer's disease brains examined by in situ hybridization. Exp. Neurol. 182, 322-334

Pitts, W. J., Vaccaro, W., Huynh, T., Leftheris, K., Roberge, J. Y., Barbosa, J., Guo, J., Brown, B., Watson, A., Donaldson, K., Starling, G. C., Kiener, P. A., Poss, M. A., Dodd, J. H., and Barrish, J. C. (2004). Identification of purine inhibitors of phosphodiesterase 7 (PDE7). Bioorg. Med. Chem. Lett. 14, 2955-2958.

Podzuweit, T., Nennstiel, P., and Muller, A. (1995). Isozyme selective inhibition of cGMP-stimulated cyclic nucleotide phosphodiesterases by erythro-9-(2-hydroxy-3-nonyl) adenine. Cell. Signal. 7, 733-738.

Porst, H., Padma-Nathan, H., Giuliano, F., Anglin, G., Varanese, L., and Rosen, R. (2003). Efficacy of tadalafil for the treatment of erectile dysfunction at 24 and 36 hours after dosing: a randomized controlled trial. Urology 62, 121-125; discussion 125-126.

Poschet, J. F., Timmins, G. S., TaylorCousar, J. L., Ornatowski, W., Fazio, J., Perkett, E., Wilson, K. R., Yu, H. D., de Jonge, H. R., and Deretic, V. (2007). Pharmacological modulation of cGMP levels by phosphodiesterase 5 inhibitors as a therapeutic strategy for treatment of respiratory pathology in cystic fibrosis. Am. J. Physiol. Lung Cell Mol. Physiol. 293, L712-719.

Prickaerts, J., van Staveren, W. C., Sik, A., Markerink-van Ittersum, M., Niewohner, U., van der Staay, F. J., Blokland, A., and de Vente, J. (2002). Effects of two selective phosphodiesterase type 5 inhibitors, sildenafil and vardenafil, on object recognition memory and hippocampal cyclic GMP levels in the rat. Neuroscience 113, 351-361.

Reed, T. M., Repaske, D. R., Snyder, G. L., Greengard, P., and Vorhees C. V. (2002). Phosphodiesterase 1B knock-out mice exhibit exaggerated locomotor hyperactivity and DARPP-32 phosphorylation in response to dopamine agonists and display impaired spatial learning. J. Neurosci. 22, 5188-5197.

Repaske, D. R., Swinnen, J. V., Jin, S. L., Van Wyk, J. J., and Conti, M. (1992). A polymerase chain reaction strategy to identify and clone cyclic nucleotide phosphodiesterase cDNAs. Molecular cloning of the cDNA encoding the 63$\mathrm{kDa}$ calmodulin-dependent phosphodiesterase. J. Biol. Chem. 267, 18683-18688.

Riordan, J. R., Rommens, J. M., Kerem, B., Alon, N., Rozmahel, R., Grzelczak, Z., Zielenski, J., Lok, S., Plavsic, N., Chou, J. L., Iannuzzi, M. C., Collins, F. S., and Tsui, L. P. (1989). Identification of the cystic fibrosis gene: cloning and characterization of complementary DNA. Science 245, 1066-1073.

Rivet-Bastide, M., Vandecasteele, G., Hatem, S., Verde, I., Benardeau, A., Mercadier, J. J., and Fischmeister, R. (1997). cGMP-stimulated cyclic nucleotide phosphodiesterase regulates the basal calcium current in human atrial myocytes. J. Clin. Invest. 99, 2710-2718.

Robert, R., Carlile, G. W., Pavel, C., Liu, N., Anjos, S. M., Liao, J., Luo, Y., Zhang, D., Thomas, D. Y., and Hanrahan, J. W. (2008). Structural analog of sildenafil identified as a novel corrector of the 
F508del-CFTR trafficking defect. Mol. Pharmacol. 73, 478-489.

Rosman, G. J., Martins, T. J., Sonnenburg, W. K., Beavo, J. A., Ferguson, K., and Loughney, K. (1997). Isolation and characterization of human cDNAs encoding a cGMP-stimulated $3^{\prime}, 5^{\prime}$-cyclic nucleotide phosphodiesterase. Gene 191, 89-95.

Rowe, S. M., Miller, S., and Sorscher, E. J. (2005). Cystic fibrosis. N. Engl. J. Med. 352, 1992-2001.

Rutten, K., Van Donkelaar, E. L., Ferrington, L., Blokland, A., Bollen, E., Steinbusch, H. W., Kelly, P. A., and Prickaerts, J. H. (2009). Phosphodiesterase inhibitors enhance object memory independent of cerebral blood flow and glucose utilization in rats. Neuropsychopharmacology 34, 1914-1925.

Sadhu, K., Hensley, K., Florio, V. A., and Wolda, S. L. (1999). Differential expression of the cyclic GMP-stimulated phosphodiesterase PDE2A in human venous and capillary endothelial cells. J. Histochem. Cytochem. 47, 895-906.

Sasaki, T., Kotera, J., Yuasa, K., and Omori, K. (2000). Identification of human PDE7B, a cAMP-specific phosphodiesterase. Biochem. Biophys. Res. Commun. 271, 575-583.

Scott, A. I., Perini, A. F., Shering, P. A., and Whalley, L. J. (1991). In-patient major depression: is rolipram as effective as amitriptyline? Eur. J. Clin. Pharmacol. 40, 127-129.

Sebkhi, A., Strange, J. W., Phillips, S. C., Wharton, J., and Wilkins, M. R. (2003). Phosphodiesterase type 5 as a target for the treatment of hypoxiainduced pulmonary hypertension. Circulation 107, 3230-3235.

Sermet-Gaudelus, I., De Boeck, K., Casimir, G. J., Vermeulen, F., Leal, T., Mogenet, A., Roussel, D., Fritsch, J., Constantine, S., Reha, A., Hirawat, S., Miller, N. L., Ajayi, T., Elfring, G. L., and Miller, L. (2010). Ataluren (PTC124) induces CFTR protein expression and activity in children with nonsense mutation cystic fibrosis. Am. J. Respir. Crit. Care Med. 182, 1262-1272.

Shin, D. D., Brandimarte, F., De Luca, L., Sabbah, H. N., Fonarow, G. C., Filippatos, G., Komajda, M., and Gheorghiade, M. (2007). Review of current and investigational pharmacologic agents for acute heart failure syndromes. Am. J. Cardiol. 99, $4 \mathrm{~A}-23 \mathrm{~A}$.

Smith, S. J., Brookes-Fazakerley, S., Donnelly, L. E., Barnes, P. J., Barnette, M. S., and Giembycz, M. A. (2003). Ubiquitous expression of phosphodiesterase 7A in human proinflammatory and immune cells. Am. J. Physiol. 284, L279-L289.

Smith, S. N., Middleton, P. G., Chadwick, S., Jaffe, A., Bush, K. A., Rolleston, S., Farley, R., Delaney, S. J., Wainwright, B., Geddes, D. M., and Alton, E. W. (1999). The in vivo effects of milrinone on the airways of cystic fibrosis mice and human subjects. Am. J. Respir. Cell Mol. Biol. 20, 129-134.

Soderling, S. H., Bayuga, S. J., and Beavo, J. A. (1998a). Cloning and characterization of a cAMP-specific cyclic nucleotide phosphodiesterase. Proc. Natl. Acad. Sci. U.S.A. 95, 8991-8996.

Soderling, S. H., Bayuga, S. J., and Beavo, J. A. (1998b). Identification and characterization of a novel family of cyclic nucleotide phosphodiesterases. J. Biol. Chem. 273, 15553-15558.

Soderling, S. H., Bayuga, S. J., and Beavo, J. A. (1999). Isolation and characterization of a dual-substrate phosphodiesterase gene family: PDE10A. Proc. Natl. Acad. Sci. U.S.A. 96, 7071-7076.

Soderling, S. H., and Beavo, J. A. (2000). Regulation of cAMP and cGMP signaling: new phosphodiesterases and new functions. Curr. Opin. Cell Biol. $12,174-179$.

Staab, A., Tillmann, C., Forgue, S. T., MacKie, A., Allerheiligen, S. R., Rapado, J., and Troconiz, I. F. (2004). Population dose-response model for tadalafil in the treatment of male erectile dysfunction. Pharm. Res. 21, 1463-1470.

Stark, S., Sachse, R., Liedl, T., Hensen, J. Rohde, G., Wensing, G., Horstmann, R., and Schrott, K. M. (2001). Vardenafil increases penile rigidity and tumescence in men with erectile dysfunction after a single oral dose. Eur. Urol. 40, 181-188; discussion 189-190.

Sullivan, M., Egerton, M., Shakur, Y., Marquardsen, A., and Houslay, M. D. (1994). Molecular cloning and expression, in both COS-1 cells and S. cerevisiae, of a human cytosolic type-IVA, cyclic AMP specific phosphodiesterase (hPDE-IVAh6.1). Cell. Signal. 6, 793-812.

Suvarna, N. U., and O'Donnell, J. M. (2002). Hydrolysis of N-methyl-Daspartate receptor-stimulated cAMP and cGMP by PDE4 and PDE2 phosphodiesterases in primary neuronal cultures of rat cerebral cortex and hippocampus. J. Pharmacol. Exp. Ther. 302, 249-256.

Takeuchi, K., Yagi, K., Kato, S., and Ukawa, H. (1997). Roles of prostaglandin E-receptor subtypes in gastric and duodenal bicarbonate secretion in rats. Gastroenterology 113, 1553-1559.

Tenor, H., Hatzelmann, A., Kupferschmidt, R., Stanciu, L., Djukanovic, R., Schudt, C., Wendel, A., Church, M. K., and Shute, J. K. (1995a). Cyclic nucleotide phosphodiesterase isoenzyme activities in human alveolar macrophages. Clin. Exp. Allergy 25, 625-633.

Tenor, H., Hatzelmann, A., Wendel, A., and Schudt, C. (1995b). Identification of phosphodiesterase IV activity and its cyclic adenosine monophosphate-dependent up-regulation in a human keratinocyte cell line (HaCaT). J. Invest. Dermatol. 105, 70-74.

Tenor, H., Staniciu, L., Schudt, C., Hatzelmann, A., Wendel, A. Djukanovic, R., Church, M. K. and Shute, J. K. (1995c). Cyclic nucleotide phosphodiesterases from purified human CD4+ and CD8+ T lymphocytes. Clin. Exp. Allergy 25, 616-624.

Truss, M. C., Stief, C. G., Uckert, S. Becker, A. J., Wefer, J., Schultheiss, D., and Jonas, U. (2001). Phosphodiesterase 1 inhibition in the treatment of lower urinary tract dysfunction: from bench to bedside. World J. Urol. $19,344-350$.

Tsai, L. C., Shimizu-Albergine, M., and Beavo, J. A. (2011). The high affinity cAMP-specific phosphodiesterase 8B (PDE8B) controls steroidogenesis in the mouse adrenal gland. Mol. Pharmacol. 79 , 639-648.

van der Staay, F. J., Rutten, K., Bärfacker, L., Devry, J., Erb, C., Heckroth, H., Karthaus, D., Tersteegen, A., van Kampen, M., Blokland, A., Prickaerts, J., Reymann, K. G., Schröder, U. H., and Hendrix, M. (2008). The novel selective PDE9 inhibitor BAY 73-6691 improves learning and memory in rodents. Neuropharmacology 55 908-918.

van Doorninck, J. H., French, P. J., Verbeek, E., Peters, R. H., Morreau, H. Bijman, J., and Scholte, B. J. (1995). A mouse model for the cystic fibrosis delta f508 mutation. EMBO J. 14, 4403-4411.

Van Goor, F., Straley, K. S., Cao, D. Gonzalez, J., Hadida, S., Hazlewood, A., Joubran, J., Knapp, T., Makings, L. R., Miller, M., Neuberger T., Olson, E., Panchenko, V., Rader J., Singh, A., Stack, J. H., Tung, R., Grootenhuis, P. D., and Negulescu, P. (2006). Rescue of DeltaF508-CFTR trafficking and gating in human cystic fibrosis airway primary cultures by small molecules. Am. J. Physiol. Lung Cell Mol. Physiol. 290, L1117-L1130.

Vandecasteele, G., Verde, I., RuckerMartin, C., Donzeau-Gouge, P., and Fischmeister, R. (2001). Cyclic GMP regulation of the L-type $\mathrm{Ca}(2+)$ channel current in human atrial myocytes. J. Physiol. (Lond.) 533, 329-340.

Vang, A. G., Ben-Sasson, S. Z., Dong, H., Kream, B., DeNinno, M. P., Claffey, M. M., Housley, W., Clark, R. B., Epstein, P. M., and Brocke, S. (2010). PDE8 regulates rapid Teff cell adhesion and proliferation independent of ICER. PLoS ONE 5, el2011. doi:10.1371/journal.pone.0012011

Vasta, V., Shimizu-Albergine, M., and Beavo, J. A. (2006). Modulation of Leydig cell function by cyclic nucleotide phosphodiesterase $8 \mathrm{~A}$. Proc. Natl. Acad. Sci. U.S.A. 103, 19925-19930.

Vergne, F., Bernardelli, P., Lorthiois, E. Pham, N., Proust, E., Oliveira, C. Mafroud, A. K., Royer, F., Wrigglesworth, R., Schellhaas, J., Barvian, M., Moreau, F., Idrissi, M., Tertre, A., Bertin, B., Coupe, M., Berna, P., and Soulard, P. (2004). Discovery of thiadiazoles as a novel structural class of potent and selective PDE7 inhibitors. Part 1: design, synthesis and structure-activity relationship studies. Bioorg. Med. Chem. Lett. 14, 4607-4613.

Wang, P., Wu, P., Egan, R. W., and Billah, M. M. (2001). Human phosphodiesterase $8 \mathrm{~A}$ splice variants: cloning, gene organization, and tissue distribution. Gene 280, 183-194.

Wang, T., Liu, Y., Chen, L., Wang, X., Hu, X. R., Feng, Y. L., Liu, D. S. Xu, D., Duan, Y. P., Lin, J., Ou, X. M., and Wen, F. Q. (2009). Effect of sildenafil on acrolein-induced airway inflammation and mucus production in rats. Eur. Respir. J. 33, 1122-1132.

Weeks, J. L. II, Zoraghi, R., Francis, S. H., and Corbin, J. D. (2007). N-Terminal domain of phosphodiesterase-11A4 (PDE11A4) decreases affinity of the catalytic site for substrates and tadalafil, and is involved in oligomerization. Biochemistry 46, 10353-10364.

Wells, J. N., Wu, Y. J., Baird, C. E. and Hardman, J. G. (1975). Phosphodiesterases from porcine coronary arteries: inhibition of separated forms by xanthines, papaverine, and cyclic nucleotides. Mol. Pharmacol. 11, 775-783.

Wharton, J., Strange, J. W., Moller, G. M., Growcott, E. J., Ren, X., Franklyn, 
A. P., Phillips, S. C., and Wilkins, M. R. (2005). Antiproliferative effects of phosphodiesterase type 5 inhibition in human pulmonary artery cells. Am. J. Respir. Crit. Care Med. 172, 105-113.

Xu, R. X., Rocque, W. J., Lambert, M. H., Vanderwall, D. E., Luther, M. A., and Nolte, R. T. (2004). Crystal structures of the catalytic domain of phosphodiesterase $4 \mathrm{~B}$ complexed with AMP, 8-Br-AMP, and rolipram. J. Mol. Biol. 337, 355-365.

Yan, C., Zhao, A. Z., Bentley, J. K., Loughney, K., Ferguson, K., and Beavo, J. A. (1995). Molecular cloning and characterization of a calmodulin-dependent phosphodiesterase enriched in olfactory sensory neurons. Proc. Natl. Acad. Sci. U.S.A. 92, 9677-9681.

Yang, S. W., Smotryski, J., McElroy, W. T., Tan, Z., Ho, G., Tulshian,
D., Greenlee, W. J., Guzzi, M., Zhang, X., Mullins, D., Xiao, L., Hruza, A., Chan, T. M., Rindgen, D., Bleickardt, C., and Hodgson, R. (2012). Discovery of orally active pyrazoloquinolines as potent PDE10 inhibitors for the management of schizophrenia. Bioorg. Med. Chem. Lett. 22, 235-239.

Yu, S. M., Hung, L. M., and Lin, C. C. (1997). cGMP-elevating agents suppress proliferation of vascular smooth muscle cells by inhibiting the activation of epidermal growth factor signaling pathway. Circulation 95, 1269-1277.

Zhang, H. T., Zhao, Y., Huang, Y., Dorairaj, N. R., Chandler, L. J., and O'Donnell, J. M. (2004). Inhibition of the phosphodiesterase 4 (PDE4) enzyme reverses memory deficits produced by infusion of the MEK inhibitor U0126 into the CAl subregion of the rat hippocampus. Neuropsychopharmacology 29, 1432-1439.

Zhang, L., Murray, F., Zahno, A., Kanter, J. R., Chou, D., Suda, R., Fenlon, M., Rassenti, L., Cottam, H., Kipps, T. J., and Insel, P. A. (2008). Cyclic nucleotide phosphodiesterase profiling reveals increased expression of phosphodiesterase 7B in chronic lymphocytic leukemia. Proc. Natl. Acad. Sci. U.S.A. 105, 19532-19537.

Zhang, X., Feng, Q., and Cote, R. H. (2005). Efficacy and selectivity of phosphodiesterase-targeted drugs in inhibiting photoreceptor phosphodiesterase (PDE6) in retinal photoreceptors. Invest. Ophthalmol. Vis. Sci. 46, 3060-3066.

Conflict of Interest Statement: The authors declare that the research was conducted in the absence of any commercial or financial relationships that could be construed as a potential conflict of interest.

Received: 29 June 2012; accepted: 24 August 2012; published online: 18 September 2012

Citation: Noel S, Dhooghe B and Leal $T$ (2012) PDE5 inhibitors as potential tools in the treatment of cystic fibrosis. Front. Pharmacol. 3:167. doi: 10.3389/fphar.2012.00167

This article was submitted to Frontiers in Pharmacology of Ion Channels and Channelopathies, a specialty of Frontiers in Pharmacology.

Copyright (๑) 2012 Noel, Dhooghe and Leal. This is an open-access article distributed under the terms of the Creative Commons Attribution License, which permits use, distribution and reproduction in other forums, provided the original authors and source are credited and subject to any copyright notices concerning any third-party graphics etc. 